\title{
PENGEMBANGAN SISTEM PENCARIAN LOKASI KULINER DI KOTA MALANG DENGAN LOCATION BASED SERVICE
}

\author{
Fitri Maharany ${ }^{1}$, Ulla Delfana Rosiani ${ }^{2}$, Dyah Ayu Irawati ${ }^{3}$ \\ ${ }^{123}$ Program Studi Teknik Informatika, Jurusan Teknik Elektro, Politeknik Negeri Malang \\ ${ }^{1}$ fitrimaharany@gmail.com, ${ }^{2}$ ullarosi@gmail.com,${ }^{3}$ dyah.ayu@polinema.ac.id
}

\begin{abstract}
Abstrak
Kota Malang merupakan salah satu kota tujuan wisata. Wisata yang disajikan tidak hanya berupa wisata alam, tetapi juga wisata kuliner. Perkembangan kuliner di Malang menjadi semakin pesat sehingga semakin banyak pula wisatawan yang ingin mengunjunginya. Namun, karena keterbatasan informasi membuat permasalahan bagi wisatawan yang ingin berkunjung ke lokasi kuliner tersebut.Oleh karena itu, dikembangkan sebuah Sistem Pencarian Lokasi Kuliner di Kota Malang dengan Location Based Service(LBS) yang menggunakan sistem operasi Android. LBS adalah implementasi dari mobile GIS (Geographic Information System), yang menampilkan posisi secara geografis keberadaan posisi pengguna dari perangkat mobile melalui GPS (Global Positioning System) sehingga dapat mengidentifikasi lokasi seperti lokasi kuliner dari pengguna. Sistem Pencarian Lokasi Kuliner di Kota Malang ini dapat menampilkan informasi mengenai lokasi kuliner di kota Malang.Sistem ini mempunyaibeberapa fitur yaitu, menemukan lokasi kuliner terdekat, pencarian berdasarkan kategori dan rating, menampilkan rute menuju lokasi kuliner, menambahkan review lokasi kuliner, memberikan rating lokasi kuliner, serta menambahkan lokasi kuliner baru. Dengan fitur tersebut maka Sistem Pencarian Lokasi Kuliner di Kota Malang ini dapat menyajikan informasi dan pencarian lokasi kuliner di Kota Malang ke dalam sebuah sistem dengan pendekatan teknologi informasi serta referensi tambahan bagi pihak-pihak yang memerlukan informasi berkaitan dengan kuliner yang dapat membantu mengembangkan obyek kuliner tersebut.
\end{abstract}

Kata Kunci: Kuliner, Mobile GIS, LBS, GPS

\section{Pendahuluan}

Kota Malang merupakan salah satu kota tujuan wisata, berdasarkan data dari Dinas Kebudayaan dan Pariwisata pada tahun 2009, jumlah wisatawan yang berkunjung ke kota pendidikan ini mencapai 102.125 orang dan jumlah tersebut termasuk wisatawan mancanegara mencapai 4.630 orang. Wisata yang terdapat di kota Malang tidak kalah dengan kota-kota tujuan wisata lainnya, seperti wisata dalam hal belanja, rekreasi, budaya maupun wisata kuliner.

Seiring berjalannya waktu, perkembangan kuliner di Malang semakin pesat dan semakin banyak pula wisatawan yang ingin mengunjungi dan mencoba.Social media berperan penting sebagai wadah informasi dan diskusi aneka kuliner di kota Malang bagi wisatawan luar maupun dalam kota Malang sendiri. Melalui social media juga masyarakat dapat mengetahui review atau testimonial dari setiap lokasi kuliner yang ada di kota Malang.

Belum adanya sistem pencarian lokasi kuliner di Kota Malang, membuat wisatawan luar atau pendatang mempunyai kendala dalam mencari aneka lokasi kuliner di kota Malang. Oleh karena itu, diperlukan suatu sistem pencarian lokasi kuliner di kota Malang yang bertujuan memudahkan wisatawan maupun warga kota Malang untuk menemukan lokasi kuliner yang diinginkan.Location Based Service(LBS) adalah implementasi dari mobile GIS, yang menampilkan posisi secara geografis keberadaan perangkat mobile, sehingga dapat mengidentifikasi lokasi seperti lokasi kuliner dari user atau pengguna. Menurut The Pew Research Center's pada bulan Mei 2011, sebanyak 55\% pengguna smartphone di kalangan dewasa menggunakan sistem dengan teknologi LBS sebagai penunjuk arah berdasarkan rekomendasi. Diharapkan dengan teknologi LBS, pencarian lokasi kuliner di kota Malang dapat diakses dengan mudah.

\subsection{Rumusan Masalah}

Berdasarkan latar belakang di atas, maka rumusan masalah yang didapatkan adalah :

a.Bagaimana membangun sistem yang dapat memberikan informasi tentang informasi lokasi kuliner di kota Malang.

b. Bagaimana penerapan teknologi Location Based Service dalam pencarian lokasi kuliner di kota Malang.

\subsection{Batasan Masalah}

Batasan masalah dalam pembuatan sistem ini, diantaranya sebagai berikut :

a.Ruang lingkup maupun lokasi kuliner yang ditampilkan hanya mencakup wilayah kota Malang. b.Menggunakan handphone yang berbasis sistem operasi Android sebagai penerapan aplikasi, dengan sistem operasi minimal Ice Cream Sandwich.

c.Data yang digunakan diperoleh berdasarkan data pada group social media Facebook Malang Kuliner. d.Peta diperoleh melalui API Google Maps. 
e.Penambahan lokasi kuliner dilakukan olehowner atau pemilik usaha kuliner melalui perangkat mobile dan diolah dengan berbasis web.

f.Sistem menyediakan fasilitas rute menuju lokasi kuliner yang diperoleh berdasarkan API Google, sehingga merupakan static graph, bukan direction graph.

\subsection{Tujuan Penelitian}

Berdasarkan rumusan masalah yang didapat, maka tujuan dari pembuatan sistem ini adalah :

a.Membangun sebuah sistem yang dapat memberikan informasi tentang lokasi kuliner di kota Malang melalui Sistem Pencarian Lokasi Kuliner di Kota Malang.

b.Dapat menampilkan pencarian lokasi kuliner di kota Malang dengan menerapkan teknologi Location Based Service.

\section{Metode}

\subsection{Landasan Teori}

a.Sistem Informasi Geografis (GIS)

Sistem Informasi Geografis (GIS) adalah suatu sistem informasi menyangkut keberadaan obyek di permukaan bumi berikut informasi yang terkandung di dalamnya yang menpunyai keterkaitan secara geografis dengan obyek lainnya.Dengan sistem ini data dapat dikelola, dilakukan manipulasi untuk keperluan analisis secara komprehensif.(Haji Sutan, Sulianto Adi 2010)

b. Location Based Service

Teknologi Location Based Service (LBS) merupakan salah satu bagian dari implementasi mobile GIS yang lebih cenderung memberikan fungsi terapan sehari-hari seperti menampilkan direktori kota, navigasi kendaraan, pencarian alamat serta jejaring sosial dibanding fungsionalitas pada teknologi GIS populer untuk Field Based GIS (Riyanto, 2010).

c. Android SDK

Android SDK perangkat lunak yang digunakan dalam pengembangan aplikasi pada android berisikan debugger, Library, dokumentasi, kode contoh, dan tutorial yang dapat diperoleh dari http://developer.android.com/sdk/index.html.Android SDK adalah tools API (Application Programming Interface) yang diperlukan untuk mengembangkan aplikasi pada platform Android yang menggunakan bahasa pemrograman Java. (Eko Priyo Utomo, 2012). d. Google Maps

Google Maps adalah layanan pemetaan berbasis web service yang disediakan oleh Google dan bersifat gratis, yang memiliki kemampuan terhadap banyak layanan pemetaan berbasis web. Google Maps juga memiliki sifat server side, yaitu peta yang tersimpan pada server Google dapat dimanfaatkan oleh pengguna. Google Maps API adalah suatu library yang berbentuk javascript yang berguna untuk memodifikasi peta yang ada di Google Maps sesuai kebutuhan. Untuk membangun aplikasi yang memanfaatkan Google Maps di desktop dan mobile device maka akan digunakan Google Maps Javascript API v3 yang memiliki keunggulan lebih cepat dari versi sebelumnya.

e. Google Maps API

Google Maps APIadalah suatu library yang berbentuk JavaScript, dan dapat ditampilkan melalui web dengan HTML serta koneksi internet yang stabil. Dengan menggunakan Google Maps API, maka akan menghemat waktu dan biaya untuk membangun aplikasi peta digital, sehingga hanya fokus pada data yang ditampilkan. Google Maps API sangat mendukung developer dalam pengerjaan aplikasi yang membutuhkan peta digital, seperti foursquare atau path. Beberapa fitur dari Google Maps API ini seperti marker sebuah tempat, garis penghubung antar tempat satu dengan tempat lain, polygon, dan lain-lain.

f. jQuery Mobile

jQuery Mobile merupakan framework yang dibangun di atas jQuery yang menyediakan berbagai elemen antarmuka pengguna (user interface) dalam pembuatan aplikasi mobile ( Eko Priyo Utomo, 2012 ) .

g.PhoneGap

PhoneGap adalah salah satu framework open source yang memungkinkan aplikasi berbasis web (html) menjadi aplikasi native. PhoneGap menyediakan framework untuk membuat aplikasi native untuk semua jenis platform sistem operasi smartphone atau tablet yang ada (Android, iOs, Blackberry, Windows Phone 7, Symbian, dll.)

h. Formula Haversine

Rumus haversine adalah persamaan yang penting pada navigasi, memberikan jarak lingkaran besar antara dua titik pada permukaan bola (bumi) berdasarkan bujur dan lintang. Rumus haversine mengasumsikan bulat bumi dan tidak mencakup ellipsoidal. Penggunaan rumus ini cukup akurat untuk sebagian besar perhitungan, juga mengabaikan ketinggian bukit dan kedalaman lembah di permukaan bumi (Uyun dan Madikhatun,2011)

Spherical Law of Cosines

Metode formula haversine di atas diciptakan ketika tingkat presisi hasil penghitungan masih sangat terbatas. Namun sekarang, penghitungan komputer dapat memberikan tingkat presisi yang sangat akurat sehingga dengan menggunakan rumus spherical law of cosine sederhana, maka dapat menentukan posisi dengan cukup akurat. Perhitungan jarak antara 2 posisi dalam peta, digunakan teori Spherical Law of Cosines. Data posisi yang digunakan adalah nilai dari longitude dan latitude dari pengguna dan tempat yang dipilih. Dalam penelitian ini, akan dilakukan proses pencarian jarak berdasarkan radius yang direpresentasikan melalui posisi garis lintang (latitude) dan garis bujur (longitude). Berikut rumus Spherical Law of Cosines yang diterapkan pada penelitian ini : 
$\mathrm{d}=\quad \operatorname{acos} \omega]$ (sinfo (lat 1$) \times \sin \%($ lat 2$) \times \cos \sigma($ long2long1) $) \times \mathrm{R}$ ]

Keterangan :

$\mathrm{R}=$ jari-jari bumi sebesar $6371(\mathrm{~km})$

$\mathrm{d}=\operatorname{jarak}(\mathrm{km})$

\subsection{Kerangka Konsep Penelitian}

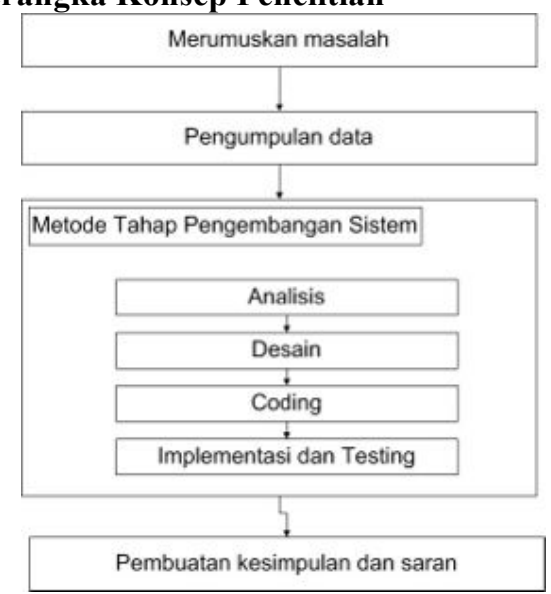

Gambar 1 Kerangka Konsep Penelitian

\section{Analisa Desain Sistem}

\subsection{Desain Arsistektur Sistem}

Arsitektur Sistem Pencarian Lokasi Kuliner di Kota Malang yang akan dibangun merupakan sebuah sistem yang terpasang pada perangkat piranti mobile. Sistem ini menggunakan teknologi Location Based Service (LBS), secara sederhana desain arsitektur sistem dapat dilihat melalui gambar :

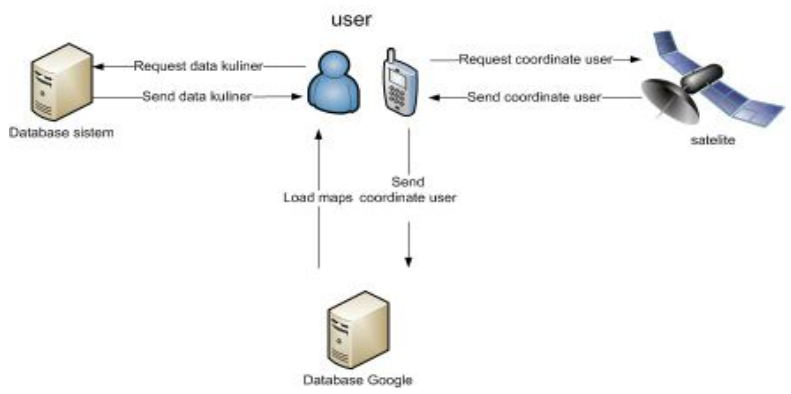

Gambar 2 Desain Arsitektur Sistem

\subsection{Work Breakdown Structure (WBS)}

WBS adalah suatu metode pengorganisaian proyek menjadi struktur pelaporan hierarakis. WBS digunakan untuk melakukan Breakdown atau memecahkan tiap proses pekerjaan menjadi lebih detail. Hal ini dimaksudkan agar proses perencanaan proyek memiliki tingkat yang lebih baik. Pada Sistem Pencarian Lokasi Kuliner di Kota Malang ini data yang digunakan adalah lokasi kuliner di kota Malang, layanan yang diberikan adalah pencarian lokasi kuliner berdasarkan kategori dan rating, peta lokasi kuliner dan rute terhadap lokasi kuliner. Laporan yang diberikan berupa review atau ulasan mengenai lokasi kuliner.

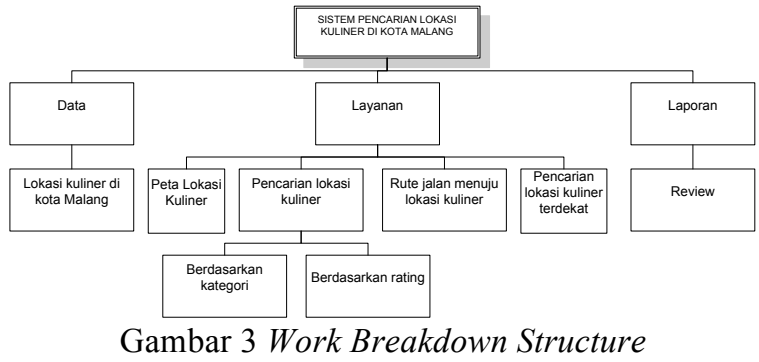

\subsection{Use Case Diagram}

Use case adalah rangkaian atau uraian sekelompok yang saling terkait dan membentuk sistem secara teratur yang dilakukan atau diawasi oleh sebuah aktor. Berikut Use Case Diagram sistem yang dibangun :

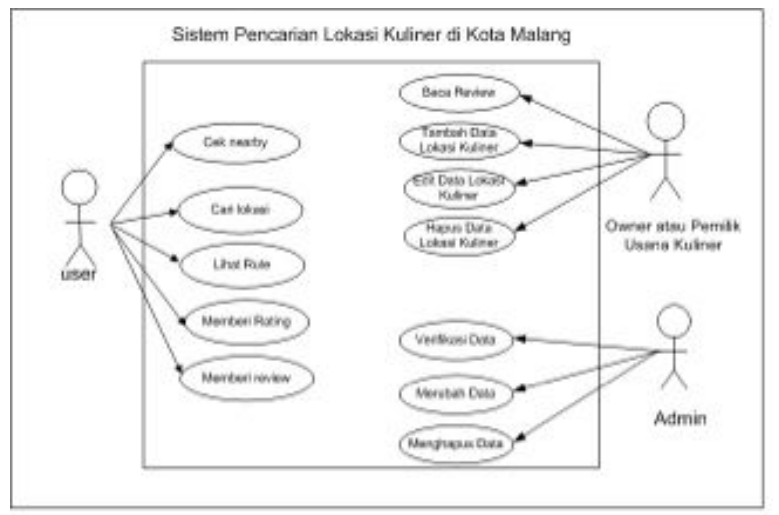

Gambar 4 Use Case Diagram

\subsection{Flowchart Pencarian Lokasi Kuliner Terdekat Berdasarkan Radius}

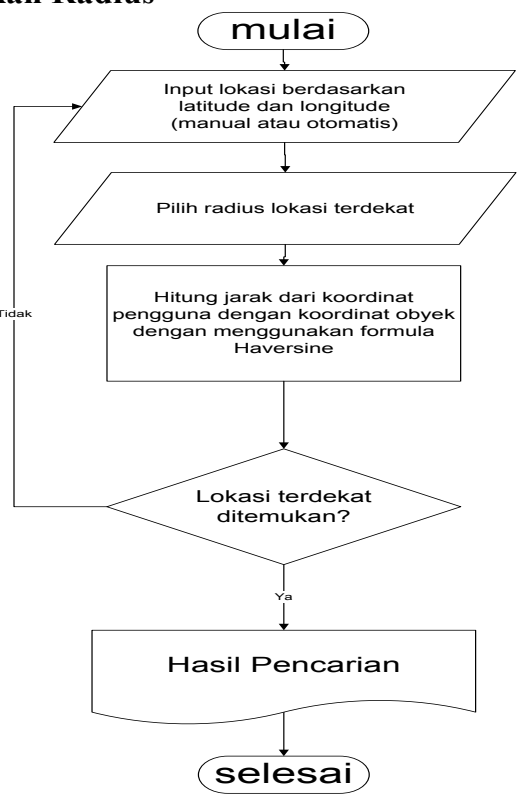

Gambar 5 Flowchart Pencarian Lokasi Kuliner Terdekat Berdasarkan Radius 


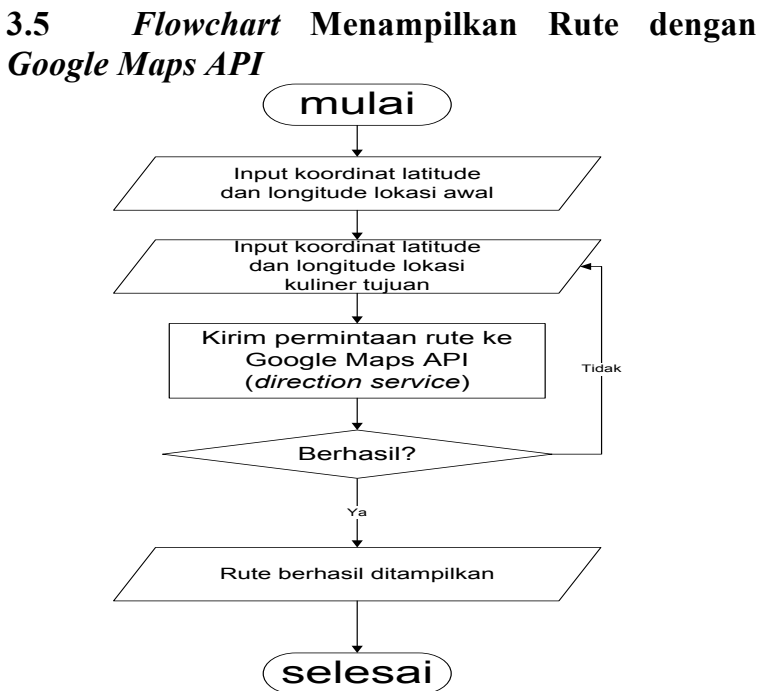

Gambar 6 Flowchart Menampilkan Rute dengan Google Maps API

\section{Hasil dan Pembahasan}

4.1 Hasil

Aplikasi android ini diperuntukkan bagi user untuk memberikan informasi pencarian lokasi kuliner serta titik lokasi kuliner pada peta berupa marker.Terdapat fitur pencarian lokasi kuliner terdekat dengan menampilkan marker posisi user dan pilihan radius untuk menampilkan titik lokasi kuliner sesuai pilihan, serta fitur untuk mencari rute dengan menampilkan marker dari lokasi GPS user ke tempat lokasi kuliner yang diinginkan.

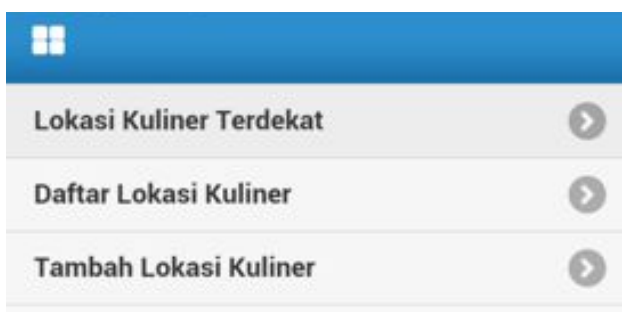

Gambar 7 Halaman Menu Utama Aplikasi Android Halaman ini merupakan halaman menu utama dari aplikasi Pengembangan Sistem Lokasi Kuliner di Kota Malang yang berisi menu-menu utama aplikasi. a. Menu Lokasi Kuliner Terdekat

Digunakan untuk melihat lokasi kuliner terdekat di sekitar posisi user. User dapat juga melakukan input posisi manual.

b.Menu Daftar Lokasi Kuliner

Digunakan untuk melihat daftar lokasi kuliner yang ingin dicari oleh user, berupa daftar lokasi kuliner di Kota Malang.

c.Menu Tambah Lokasi Kuliner

Digunakan untuk melakukan penambahan lokasi kuliner

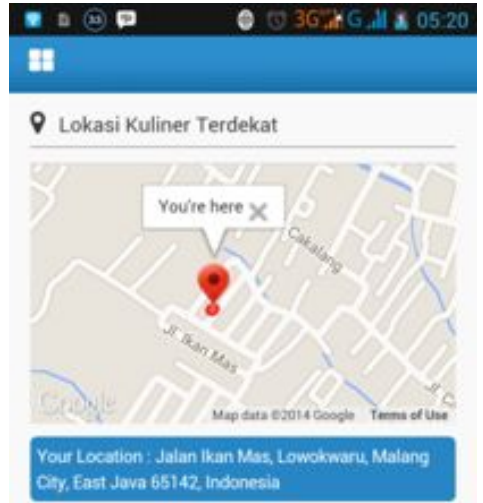

Gambar 8 Halaman Informasi Posisi User

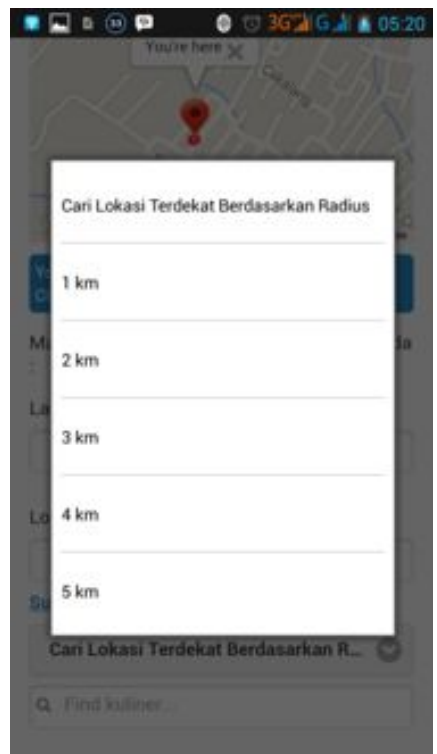

Gambar 9 Menu Pilihan Cari Lokasi Berdasarkan Radius

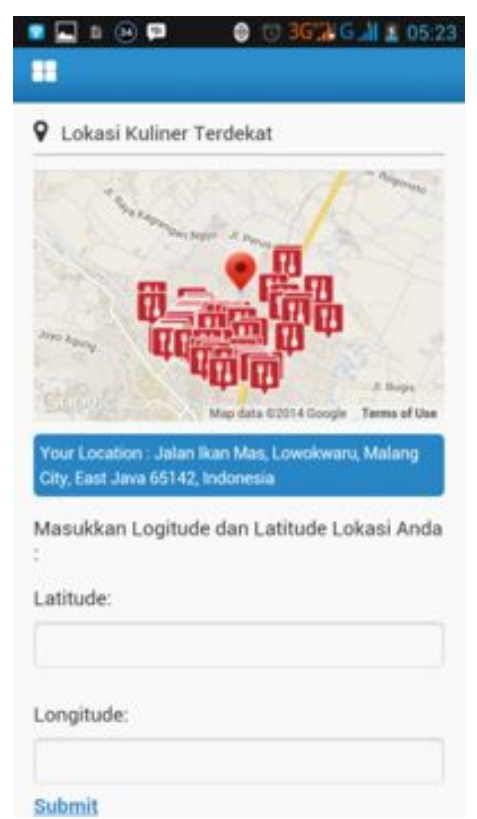

Gambar 10 Halaman Lokasi Kuliner Terdekat Berdasarkan Radius 


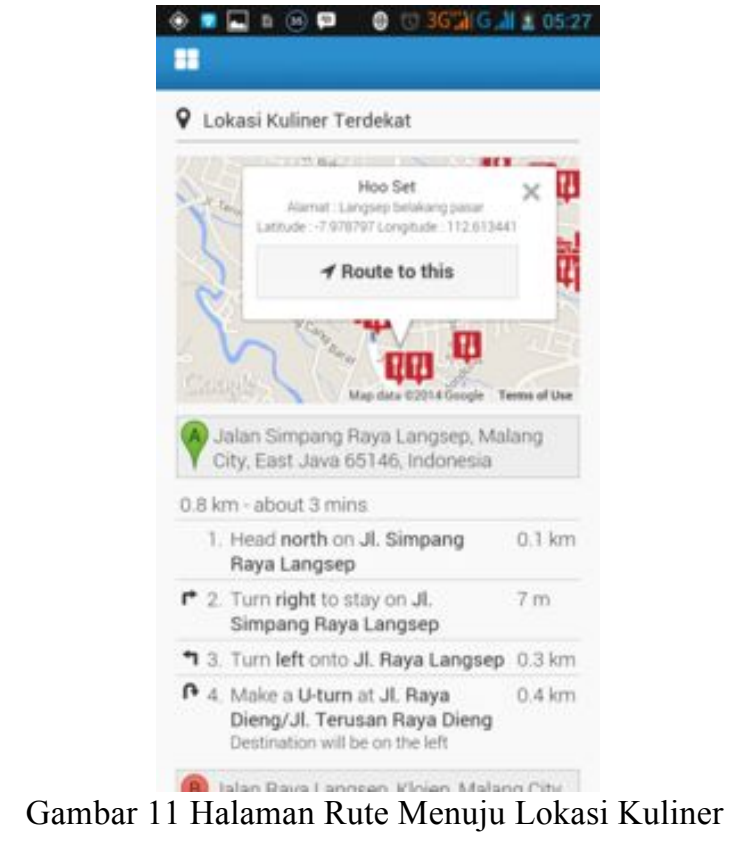

\subsection{Pembahasan}

Berdasarkan hasil pengujian aplikasi yang dilakukan maka dapat disimpulkan bahwa Sistem Pencarian Lokasi di Kota Malang yang dibangun sudah berjalan sesuai dengan yang diharapkan dan didapatkan hasil bahwa semua menu utama serta fitur-fitur yang dibuat Sistem Pencarian Lokasi Kuliner dapat berjalan sesuai fungsinya. Pada sistem ini terdapat menu utama Lokasi Kuliner Terdekat yang berisi fitur menampilkan informasi posisi pengguna, dan dapat mengetahui lokasi kuliner terdekat berdasarkan radius yang dipilih. Berikut penjelasan dari masingmasing menu :

- Lokasi Kuliner Terdekat

Dalam menu Lokasi Kuliner Terdekat, pengguna dapat mengetahui informasi posisi keberadaannya melalui bantuan GPS, dan dapat mengetahui lokasi kuliner di sekitarnya melalui pilihan radius. Setelah memilih radius yang diinginkan, maka akan muncul titik-titik lokasi kuliner yang berupa marker (icon) yang merepresentasikan letak lokasi kuliner melalui latitude dan longitude. Pengguna dapat juga melihat rute menuju lokasi kuliner yang diinginkan dengan memilih tombol Route this pada daftar lokasi kuliner terdekat maupun pada titik-titik lokasi kuliner yang ada di dalam peta. Proses pencarian lokasi terdekat ini menggunakan rumus haversine, sehingga diperoleh titik-titik lokasi kuliner yang dicari berdasarkan radius yang dipilih.

- Daftar Lokasi Kuliner

Dalam menu ini, pengguna dapat melakukan pencarian lokasi kuliner berdasarkan kategori dan rating yang dipilih. Akan muncul daftar lokasi kuliner yang dicari berdasarkan pencarian tersebut, dan apabila di klik salah satu maka akan muncul detail lokasi kuliner. Pengguna dapat memberikan rating berdasarkan pilihan angka dari 1 sampai 5, dan dapat memberikan review lokasi kuliner kepada pemilik usaha kuliner.

- Baca Review Lokasi Kuliner.

Dalam menu ini, pemilik usaha kuliner dapat melihan ulasan atau review kuliner yang dikirimkan oleh pengguna, sehingga diharapkan pemilik usaha kuliner dapat meningkatkan kualitas usaha kulinernya tersebut.

- Tambah Data Lokasi Kuliner.

Menu tambah data lokasi kuliner merupakan menu untuk memasukkan data lokasi kuliner baru dengan input nama lokasi kuliner, alamat, telepon, menu, gambar, latitude dan longitude.

- Edit Data Lokasi Kuliner.

Menu edit data lokasi kuliner bertujuan untuk merubah data kuliner yang sudah ada dengan merubah nama lokasi kuliner, alamat, telepon, menu, gambar, latitude dan longitude.

- Hapus Data Lokasi Kuliner.

Menu hapus data lokasi kuliner bertujuan untuk melakukan aktivitas penghapusan terhadap lokasi kuliner yang dipilih.

- Tambah Range Harga Kuliner

Pada menu ini, yang berhak menambah range harga kuliner adalah administrator, aktivitas ini bertujuan untuk menambahkan range harga baru ke dalam Sistem Pencarian Lokasi Kuliner di Kota Malang.

- Tambah Kategori Kuliner

Pada menu ini, yang berhak menambah kategori kuliner adalah administrator, aktivitas ini bertujuan untuk menambahkan kategori kuliner baru ke dalam Sistem Pencarian Lokasi Kuliner di Kota Malang.

\section{Analisis Location Based Service}

Berdasarkan pengujian yang telah dilakukan, maka dapat diketahui bahwa Sistem Pencarian Lokasi Kuliner di Kota Malang ini telah memenuhi konsep dari Location Based Service, seperti yang telah dijelaskan pada Landasan Teori, yaitu :

a. Mengetahui koordinat posisi pengguna, dalam sistem ini pengguna dapat mengetahui lokasi keberadaan posisi melalui alamat yang ditampilkan pada sistem di dalam menu Lokasi Kuliner Terdekat. b. Mempunyai bank data atau dapat mengakses bank data yang menyimpan data koordinat lokasi dan informasi mengenai lokasi tersebut. Sistem Pencarian Lokasi Kuliner di Kota Malang ini mempunyai data lokasi kuliner berupa koordinat latitude dan longitude yang diinputkan oleh para pemilik usaha kuliner.

c. Menghitung jarak antara posisi pengguna dengan sebuah lokasi. Perhitungan jarak yang dilakukan pada sistem ini menggunakan perhitungan berdasarkan radius dengan formula Haversine dengan teori Spherical Law of Cosines. Data posisi yang digunakan adalah nilai dari longitude dan latitude dari pengguna dan tempat yang dipilih.

d. Menampilkannya menjadi informasi yang bisa dibaca pengguna, contohnya kedalam Map (Google Map). Setelah perhitungan jarak melalui perhitungan radius, maka muncul titik-titik lokasi kuliner yang 
berupa letak koordinat lokasi kuliner pada peta Google Maps.

Analisis Perbandingan Jarak Tempuh dengan

Perhitungan Jarak Menggunakan Radius

Analisis perbandingan dilakukan dengan membandingkan jarak yang tertera pada hasil lokasi terdekat yaitu jarak yang diperoleh dari radius yang dipilih menggunakan Formula Haversinedengan jarak tempuh sebenarnya melalui rute yang ditampilkan oleh Google Maps API. Berikut daftar lokasi kuliner yang dijadikan sampel :

Lokasi awal : Jalan Kyai Haji Hasyim Asyari, Klojen, Kota Malang, Jawa Timur 65119, Indonesia

Latitude : : -7.9818940000000005

Longitude $\quad: 112.626503$

Radius $\quad:<2 \mathrm{~km}$

\begin{tabular}{|c|c|c|c|c|}
\hline No & $\begin{array}{l}\text { Nama } \\
\text { Lokasi } \\
\text { Kuliner }\end{array}$ & $\begin{array}{c}\text { Jarak } \\
\text { menggunakan } \\
\text { Formula } \\
\text { haversine }\end{array}$ & $\begin{array}{c}\text { Jarak tempuh } \\
\text { menggunakan } \\
\text { rute Google } \\
\text { Maps API }\end{array}$ & Selisih \\
\hline 1 & $\begin{array}{l}\text { Claypot } \\
\text { Menteng }\end{array}$ & $0,1 \mathrm{~km}$ & $0,3 \mathrm{~km}$ & 0,2 \\
\hline 2 & $\begin{array}{l}\text { Depot } \\
\text { Purnama }\end{array}$ & $0,2 \mathrm{~km}$ & $0,4 \mathrm{~km}$ & 0,2 \\
\hline 3 & Kairo & $0,6 \mathrm{~km}$ & $0,9 \mathrm{~km}$ & 0,3 \\
\hline 4 & $\begin{array}{l}\text { Depot } \\
\text { Semeru }\end{array}$ & $0,9 \mathrm{~km}$ & $1,6 \mathrm{~km}$ & 0,7 \\
\hline 5 & Milk Story & $1,0 \mathrm{~km}$ & $1,6 \mathrm{~km}$ & 0,6 \\
\hline 6 & $\begin{array}{l}\text { Depot } \\
\text { Widari }\end{array}$ & $1,1 \mathrm{~km}$ & $1,5 \mathrm{~km}$ & 0,4 \\
\hline 7 & Depot 59 & $1,1 \mathrm{~km}$ & $1,5 \mathrm{~km}$ & 0,4 \\
\hline 8 & $\begin{array}{l}\text { Depot } \\
\text { Flamboyan }\end{array}$ & $1,1 \mathrm{~km}$ & $1,8 \mathrm{~km}$ & 0,7 \\
\hline 9 & Bu Masto & $1,4 \mathrm{~km}$ & $2,0 \mathrm{~km}$ & 0,6 \\
\hline 10 & Depot 21 & $1,5 \mathrm{~km}$ & $3,3 \mathrm{~km}$ & 1,5 \\
\hline 11 & Kanton & $1,6 \mathrm{~km}$ & $3,2 \mathrm{~km}$ & 1,6 \\
\hline 12 & Alfo Talia & $1,6 \mathrm{~km}$ & $2,6 \mathrm{~km}$ & 1,0 \\
\hline 13 & $\begin{array}{l}\text { Bubur } \\
\text { Agus }\end{array}$ & $1,6 \mathrm{~km}$ & $2,4 \mathrm{~km}$ & 0,8 \\
\hline 14 & Niki Eco & $1,9 \mathrm{~km}$ & $2,5 \mathrm{~km}$ & 0,6 \\
\hline 15 & Blenger & $1,9 \mathrm{~km}$ & $2,5 \mathrm{~km}$ & 0,6 \\
\hline
\end{tabular}

Pada analisis ini, diketahui bahwa selisih jarak ratarata pada pencarian lokasi terdekat berdasarkan radius adalah $0,68 \mathrm{~km}$ atau $68 \mathrm{~m}$. Perbedaan tersebut diakibatkan oleh ketika dilakukan perhitungan jarak dengan Formula haversine, maka yang dihitung adalah posisi koordinat pengguna dengan koordinat obyek berdasarkan latitude dan longitude, kemudian ditarik garis lurus sebagai jari-jari. Sedangkan pada jarak yang ditampilkan melalui rute Google Maps terdapat perbedaan karena pada rute Google Maps menampilkan jarak sebenarnya atau jarak tempuhyaitu dengan melewati jalan-jalan sesungguhnya, seperti ketika ada jalan satu arah tetap mengikuti jalan, dan tidak ditarik garis lurus sepertiFormula haversine.

Perhitungan jarak dengan radius dengan Formula haversine ini sesuai untuk mencari lokasi terdekat dari posisi pengguna, tetapi tidak sesuai ketika diterapkan pada jarak tempuh atau jarak sebenarnya. Hal ini disebabkan karena jarak tempuh dihitung dengan melalui lintasan-lintasan sebenarnya di jalan, seperti ketika melewati jalan kecil atau ketika ada jalan searah.

\section{Kesimpulan dan Saran \\ 5.1 Kesimpulan}

Berdasarkan pembahasan yang diperoleh, maka dapat ditarik kesimpulan sebagai berikut:

a.Sistem pencarian lokasi kuliner di kota Malang dapat memberikan informasi kepada pengguna yang melakukan pencarian kuliner di kota Malang.

b.Sistem pencarian lokasi kuliner yang dibangun memberikan fasilitas kepada user untuk mengetahui lokasi kuliner yang ada di sekitar posisi user, dengan radius yang ditentukan,mencari lokasi kuliner berdasarkan kategori dan rating, memperoleh navigasi rute ke lokasi kuliner yang diinginkan, memberi rating ke lokasi kuliner dan memberi ulasan atau review lokasi kuliner.

c.Koneksi internet dan sinyal GPS mempengaruhi posisi pengguna.

d.Terdapat perbedaan antara jarak yang dihitung berdasarkan formula Haversine dan melalui rute Google Maps, hal ini dikarenakan pada formula Haversine perhitungan posisi koordinat pengguna dengan koordinat obyek berdasarkan latitude dan longitude, kemudian ditarik garis sebagai jari-jari, sehingga tampil daftar lokasi terdekat berdasarkan radius yang dipilih. Sedangkan pada jarak yang ditampilkan Google Maps terdapat perbedaan karena pada Google Maps menampilkan jarak sebenarnya dengan melewati jalan-jalan sesungguhnya, seperti ketika ada jalan satu arah tetap mengikuti jalan, dan tidak ditarik garis lurus seperti Formula haversine.

\subsection{Saran}

Untuk pengembangan sistem pencarian lokasi kuliner di kota Malang lebih lanjut agar semakin memberikan manfaat untuk user ada beberapa hal yangbisa dijadikan bahan kajian lebih lanjut yaitu :

a.Perlu adanya penambahan fitur rekomendasi dari teman.

b.Penambahan fitur galery foto kuliner.

\section{Daftar Pustaka}

Haji, Tunggul Sutan, dan Sulianto, Akhmad Adi, 2007.Sistem Informasi Geografi (SIG) Dengan Aplikasi Map Info, Penerbit Fakultas Teknologi Pertanian Universitas Brawijaya, Malang.

Lunny, Andrew, 2011. PhoneGap Beginners Guide.Brimingham : Packt Publishing Ltd.

Utomo, Priyo Eko, 2012. Mobile Web Programming HTML 5, CSS3, jQuery Mobile.Penerbit Andi Yogyakarta.

Riyanto, 2010.Sistem Informasi Geografis Berbasis Mobile.Penerbit Gava Media.

Uyun, S. dan Madikhatun, Y.2011.Model Rekomendasi Berbasis Fuzzy Untuk Pemilihan Sekolah Lanjutan Tingkat Atas, Jurnal Informatika.

Veness,C.,2010,Calculate distance, bearing and more between

Latitude/Longitudepoints,(http://www.movabletype.co.uk/sc ripts/latlong.html, diakses 29 Juni 2013). 